\title{
The Resiliency Psychogram of Student who Have Problems at the Study Program of Guidance and Counseling, Faculty of Education Universitas Negeri Medan
}

\author{
Asih Menanti ${ }^{*}$, Abdul Murad ${ }^{2}$, Nurmaniah $^{3}$, Nur'aini $^{4}$ \\ ${ }^{1-4)}$ Faculty of Education, Universitas Negeri Medan, Indonesia \\ *asihmenanti9@gmail.com
}

\begin{abstract}
The study aimed at knowing the level of resiliency including its psychogram to the study program students of guidance counseling in Medan State University. This research is a descriptive qualitative one employing percentage calculation. The research subjects were 89 students. The student's data was obtained through the student problem identification scale and data on the student resilience was obtained by employing Reciliency Quotient Test. The research findings showed resiliency of large number of students $(62,44 \%)$ were averagely on the level of below average, $27,77 \%$ on the level of average, and only $9,79 \%$ on the level of above average. The resiliency aspects averagely dominance on the level of below average were self efficacy, reaching out, emotion regulation, empathy. The dominant aspect on the level of average was causal analysis, and there was no dominant aspect on the level of above average. It was concluded a large number of students needed resilient character up grading, by considering resiliency psychogram.
\end{abstract}

Keywords: psychogram, resilient, student's problem.

\section{Introduction}

This research theme is student character building accordance with motto of Medan State University as "The Character Building University". Character in this research is resilient. The individual who has character of resilient was ones who have capacity to overcome and to motivate self from failure, to response healthier and productively to improve self, so he could overcome life distress [1]. Capacity of resilient is critical owned by each one, moreover in facing difficult situation in the era of industrial revolution 4.0 characterized by efficient life, large change, rapid advances in science and technology.

The resilienc described phenomenon such as invulnerable, invincible, harddy [1]. Resilient indicated spring properties, bouncy, tenacious, steadfast [2]. The resiliency consists of seven aspects shaping them, namely emotion regulation, impulse control, optimism, causal analysis, empathy, self-efficacy, and reaching out [3]. The seven resilience aspects are needed by individual who have a number of problems or who can be said not having significantly problem.

In milieu of Medan State University students, there are really so many students who have problems disturbing their study. The research findings conducted by Menanti et al. [4] to the counseling student in Medan State University about a number of problems owned by students indicates that holistically counseling students averagely have problems classified inclined to 
high (IH). It can be explained in details that $20,25 \%$ students have problems classified on high $(\mathrm{H}) ; 40,45 \%$ inclined to high (IH), 3,37\% inclined to low (IL), and $35,96 \%$ on low. Those data are strong reasons to conduct any up grading and solving of student's problems through character building named in this research as resilient character. Because the resilient character will be the most importance strength owned for encouraging the students success in overcoming their problems. The education implemented by students in Medan State University follows semester credit system (look at The Academic Guideline Book, Medan State University, 1918) [5] and lecturing system which requires students meeting the six compulsory assignments of each subjects, namely routine task to read literature, critical book review, critical journal review, project assignment, mini research assignment, and idea engineering. The lecturing system applied in Medan State University is expected increasing the student competence, however, part of students actually have been experiencing some difficulties to follow them. There are students who is able to overcome their lecturing without significantly problem, there are students who appears eustress or distress. The student distress impacts on the assignments completion without quality, learning without enough motivation, and there are apathetic tendencies for particularly students. This unfortunately effect must be solved. This research responses it by investigating the student resiliency level, so that we can know the students capacity to adapt toward difficulties situation in their lecturing.

The empirical data of lecturing system obliges the six assignments for each subject. Those could be known from research conducted by Menanti et al. [6] that indicates 5,56\% counseling students carrying out classified in no positive, 30,81\% less positive, 32,83\% enough positive, $25,25 \%$ positive, and $5,56 \%$ highly positive. It seems that totally students included no or less of positive by $36,37 \%$. These students need intensely guidance in their lecturing as well as their problems the guidance is done through resilient character building, primarily toward students who are not or less of positive to overcome their lecturing demands. The research findings done by Menanti et al. [6] also showed that counseling student resilience who orients external control locus need guidance, namely the students resilience is on below average by $29,03 \%$ and on average level by $48,39 \%$. The resiliency guidance is becoming more important because students still have unstable remnants of teenage emotions. Adolescence can experience seriously inner hardship [7].

Based on the research findings related to the counseling students' resilience level achievement who have problems above, it is crucial to follow up with in depth data exploration as efforts to provide guidance and counseling assistance departing from individual data presented in the student resilience psychogram. With this resilience psychogram, providing assistance done individually, collectively, classically, bases on detail data and more likely about objectives.

Resiliency was result from some internal and external factors [8]. The external characteristics impacting on the resilience are the milieu that supports education, training, values, familiar interaction style and non-judgmental, hope of success, giving chance to participate. While the individual characteristics are emotion impulses control, assertive communication, flexible, independent, self-motivation, self-confidence, capacity for lifelong learning. These individual internal and external factors are mutual interacting in order to possibly increase the resilience. Grotberg [9] proposed that factors impacting on resiliency were I have, I am, I can. I have was external source to increase resiliency, I am was resiliency characteristics sourced from that can be done by individual in connection with his social and interpersonal skill [9]. 
The resiliency strength owned by students makes them viewing difficulties as a challenge, not as obstacle. At the time of feeling helpless, they will soon rise back. If constrained or failed, they do not stop to search for the other solution. Owning the strong resiliency for counseling students will be absolute because they are well-prepared to be helper in his role as professional counselor or guidance counseling teacher later. Counselee/student becoming guidance subject needs reliable guidance counseling teachers and school counselor, primarily toward in the risk era of $4.0 \mathrm{IR}$.

The information benefits on problems faced by students, their resiliency as well as their psychogram are critical data for subject lecturer, academic supervisor, thesis supervisor, head of program, and head of the study program, vice dean of student affairs and so on, in guiding the students so their problems becomes mild through student resilience reinforcement. Benefits for students, they obtain feedback on the owned resilience used for resilience development themselves and can expand their knowledge toward others.

Based on the exposure about background and the importance of resiliency for students, the purpose of this research is to know the level of resiliency as well as counseling students' resilience psychogram. The steps taken for finding the answers of problems listed above, be done on the following (1) Identifying the counseling students and/or those who need resiliency improvement to determine as research subjects, (2) Collecting the counseling students' resiliency data and/or those who need resiliency coaching, (3) Processing data in order to know ( The level of the students' resiliency holistically and The level of the students' resiliency based on the resiliency shaping aspects, (4)Composing the psychogram of the counseling students' resiliency level.

This research is generally limited on effort to obtain the students' resilience data and based on the resiliency shaping aspects. The student problems are limited on physical problem, self-admittance, self-concept, self-esteem, emotion, social (self-adjustment), education and learning, interest and aptitude, moral, religion, and well-being. Resiliency is limited on the aspects of emotion regulation, impulse control, optimism, causal analysis, empathy, self-efficacy, and reaching out. The research subjects were limited on students who have a number of problems and/or also need the resilience character building, in environment of counseling students, Medan State University.

\section{Research Method}

This research is qualitative descriptive research using the percentage calculation. The research subjects were counseling students who have a number of problems, 89 students who have been following the third and fifth semester lecturing. Research subject is result of Students Problems Identification (IPS) developed by researcher. IPS was developed in form of the favorable dan unfavorable items, with five answer choices.For favorable items, answer choices on very suitable (VS)given score of 5, suitable (S)given score of 4, sometimes suitable ( SS)given score of 3, No suitable (NS)given score of 2, and Very no suitable ( VNS)given score of 1.For unfavorable items, answer choices on very suitable (VS) given score of 1, suitable (S) given score of 2, sometimes suitable (SS) given score of 3, Not suitable (NS) given score of 4 , and no very suitable (NVS) given score of 5 . The measurement result of IPSis categorized into High (H), inclined to High (IH), inclined to Low (IH), and Low (L). The higher the students problems categorization, the more having problems of IPS.

Data on the student resilience level was obtained using Resiliency Quotient Test (RQT). RQT is a standardized instrument developed by Reivich andShatte (2002). In this research, RQTis adapted into Indonesia language and its language comprehension will be tried out. 
Before that, Mataro [10] tried out validity and reliability with result $r_{x x^{\prime}}=9,903$. The validity test result showed there were still less valid items, however the items in this research were used because they are considered important.

RQT is a set of item statements with four answer choices for each items. For favorableitems with answer choices Very Self-Describing (VSD) given score of 5, Usually Self-Describing (USD) given score of 4, Enough Self-Describing (ESD) given score of 3, Sometimes Self-Describing (SSD) given score of 2, and Not Self-Describing(NSD) given score of 1. For unfavorable items, answer choices toward VSD given score of 1, USD given score of 2, ESD given score of 3, SSD given score of 4, and NSD given score of 5. The RQT measurement result was categorized on group of average, above average, and below average. The establishment of categorization average, above average, and below average was done in accordance with RQT guideline. Data analysis employed percentage calculation. Specifically RQT data, percentage of data resulted were then presented in form of psychogram. A psychogram is a term sometimes used in fields of psychology such as personality theory. None of the senses of the term are defined clearly or used consistently[11].

\section{Results and Discussion}

\subsection{Counseling Students' Problems Level}

It is holistically known that students' problems averagely were categorized inclined to high. If seen to base on the student problems aspects, it is known that $20,25 \%$ students who have problems were categorized as high, 40,45\% categorized inclined to high, 3,37\% categorized inclined to low, and $35,96 \%$ categorized on low. The data indicated that the students who includes having highly and inclined to high problems $60,70 \%$. These students need an intensely resilience improvement. The students with the inclined to low and low categorized problems, $39,33 \%$ need preventive program so that problems do not add.

\subsection{The Counseling Students' Resilience Level}

The counseling students' resilience level is presented holistically and based on the resilience aspects. The counseling students' resiliency level generally averagely $62,44 \%$ was categorized as below average, $27,77 \%$ on average, and $9,79 \%$ on above average. It seems that large number of students existing on the level of below average need the intensely resilience coaching and the students existing on the level of average need reinforcement. A small number of students existing on the level of above average need preventive program.

Table1. The Counseling Students' Resiliency Level Based on the Resiliency Aspects

\begin{tabular}{|c|c|c|c|c|c|c|c|c|c|}
\hline \multirow{3}{*}{ No } & \multirow{3}{*}{$\begin{array}{l}\text { Aspec of } \\
\text { Resiliency }\end{array}$} & \multicolumn{6}{|c|}{ Categorization } & & \multirow[b]{2}{*}{ Total } \\
\hline & & \multicolumn{2}{|c|}{$\begin{array}{c}\text { Above } \\
\text { Average }\end{array}$} & \multicolumn{2}{|c|}{ Average } & \multicolumn{2}{|c|}{$\begin{array}{c}\text { Below } \\
\text { Average }\end{array}$} & & \\
\hline & & $\mathrm{F}$ & $\%$ & $\mathrm{~F}$ & $\%$ & $\mathrm{~F}$ & $\%$ & $\mathrm{~F}$ & $\%$ \\
\hline 1 & $\begin{array}{l}\text { Emotion } \\
\text { Regulation }\end{array}$ & 2 & 2,24 & 12 & 13,49 & 75 & 84,27 & 89 & 100 \\
\hline 2 & Impulse Control & 53 & 59,56 & 31 & 34,83 & 5 & 5,61 & 89 & 100 \\
\hline 3 & Optimism & 4 & 4,50 & 43 & 48,31 & 42 & 47,19 & 89 & 100 \\
\hline 4 & Causal Analysis & 2 & 2,24 & 45 & 50,56 & 42 & 47,20 & 89 & 100 \\
\hline 5 & Empathy & 0 & 0 & 37 & 41,58 & 52 & 58,42 & 89 & 100 \\
\hline 6 & Self Efficacy & 0 & 0 & 2 & 2,24 & 87 & 97,76 & 89 & 100 \\
\hline 7 & Reaching Out & 0 & 0 & 3 & 3,38 & 86 & 96,62 & 89 & 100 \\
\hline
\end{tabular}


Data on table 1 showed that aspects of resiliency averagely mostly existing on the below average resiliency level were self efficacy (by 97,76\%); reaching out (96,62\%); emotion regulation (84,27\%); andempathyaspects $(58,42 \%)$. While aspec of causal analysisaveragely by $47,20 \%$;optimismby $47,19 \%$;impulse controlby $5,61 \%$. The resiliency aspects averagely existing on the resiliency level of above averagewere impulse control (by 59,56\%), optimismonly by $4 \%$; emotion regulationby $2 \%$; andcausal analysisby $2 \%$. The Aspect of empathy, self efficacy, andreaching out, were averagely nothing reaching the level of above average. The resiliency aspects averagely were average, the biggest percentage is aspect of causal analysisby $50,56 \%$. Followed sequentially by the optimistic aspect by $48,31 \%$; aspect of empathyby 41,58\%; aspect ofimpulse controlby 34,83\%; aspect of emotion regulationby $13,49 \%$; aspect reaching outby $3,38 \%$; and aspect of self efficacyby $2,24 \%$.

Table2 The Counseling Students' Resiliency Level on Each Students

\begin{tabular}{|c|c|c|c|c|c|c|c|c|}
\hline \multirow[t]{2}{*}{ No } & \multirow{2}{*}{$\begin{array}{l}\text { Research Subjects } \\
\text { (with Identity Code) }\end{array}$} & \multicolumn{7}{|c|}{ Resiliency elements } \\
\hline & & $\mathrm{RE}$ & $\mathrm{IC}$ & $\mathrm{O}$ & $\mathrm{CA}$ & $E$ & $\mathrm{SE}$ & $\mathrm{RO}$ \\
\hline (1) & $(2)$ & (3) & (4) & $(5)$ & (6) & $(7)$ & $(8)$ & $(9)$ \\
\hline 1 & $1-\mathrm{B} 17$ & $B A$ & $A$ & $A$ & $A$ & $B A$ & $B A$ & $B A$ \\
\hline 2 & 2-B17 & $B A$ & $A$ & $A$ & $B A$ & $B A$ & $B A$ & $B A$ \\
\hline 3 & 3-B17 & $B A$ & $A$ & $A$ & $B A$ & $B A$ & $B A$ & $B A$ \\
\hline 4 & 4-B17 & $B A$ & $A A$ & $B A$ & $B A$ & $B A$ & $B A$ & $B A$ \\
\hline 5 & $5-\mathrm{B} 17$ & $B A$ & $A$ & $B A$ & $A$ & $B A$ & $B A$ & $B A$ \\
\hline 6 & $6-\mathrm{B} 17$ & $B A$ & $B A$ & $B A$ & $B A$ & $B A$ & $B A$ & $B A$ \\
\hline 7 & 7-B17 & $B A$ & $B A$ & $A$ & $A$ & $B A$ & $B A$ & $B A$ \\
\hline 8 & 8-B17 & $B A$ & $A A$ & $B A$ & $B A$ & $B A$ & $B A$ & $B A$ \\
\hline 9 & 9- B17 & $B A$ & $A A$ & $B A$ & $B A$ & $B A$ & $B A$ & $B A$ \\
\hline 10 & 10-B17 & $B A$ & $B A$ & $B A$ & $B A$ & $B A$ & $B A$ & $B A$ \\
\hline 11 & 11-B17 & $B A$ & $B A$ & $A$ & $B A$ & $B A$ & $B A$ & $B A$ \\
\hline 12 & 12-B17 & $B A$ & $B A$ & $A$ & $A$ & $B A$ & $B A$ & $B A$ \\
\hline 13 & 13-B17 & $A$ & $B A$ & $B A$ & $A$ & $B A$ & $B A$ & $B A$ \\
\hline 14 & 14-B17 & $B A$ & $B A$ & $A$ & $A$ & $B A$ & $B A$ & $B A$ \\
\hline 15 & 15-B17 & $B A$ & $B A$ & $A$ & $B A$ & $B A$ & $B A$ & $B A$ \\
\hline 16 & 16-B17 & $B A$ & $A$ & $B A$ & $B A$ & $B A$ & $B A$ & $B A$ \\
\hline 17 & 17-B17 & $B A$ & $B A$ & $B A$ & $B A$ & $B A$ & $B A$ & $B A$ \\
\hline 18 & 18-B17 & $B A$ & $A$ & $A$ & $A$ & $B A$ & $B A$ & $B A$ \\
\hline 19 & 19-B17 & $B A$ & $B A$ & $B A$ & $A$ & $A$ & $B A$ & $B A$ \\
\hline 20 & 20-B17 & $B A$ & $A$ & $B A$ & $B A$ & $B A$ & $B A$ & $B A$ \\
\hline 21 & 21-B17 & $B A$ & $A$ & $B A$ & $B A$ & $B A$ & $B A$ & $B A$ \\
\hline 22 & 22-B17 & $B A$ & $A A$ & $A$ & $B A$ & $B A$ & $B A$ & $B A$ \\
\hline 23 & 23-B17 & $B A$ & $A$ & $A$ & $A$ & $B A$ & $B A$ & $B A$ \\
\hline 24 & 24-B17 & $B A$ & $A A$ & $A$ & $B A$ & $B A$ & $B A$ & $B A$ \\
\hline 25 & $25-\mathrm{B} 17$ & $B A$ & $A$ & $A$ & $A$ & $B A$ & $B A$ & $B A$ \\
\hline 26 & $26-\mathrm{B} 17$ & $B A$ & A & $A$ & $B A$ & $B A$ & $B A$ & $B A$ \\
\hline 27 & 27-B17 & $A$ & $A$ & $A$ & $B A$ & $B A$ & $B A$ & $B A$ \\
\hline 28 & 28-B17 & $A$ & $A$ & $A$ & $A$ & $B A$ & $B A$ & $B A$ \\
\hline 29 & 29-B17 & $B A$ & $B A$ & $A$ & $B A$ & $B A$ & $B A$ & $B A$ \\
\hline 30 & 30-B17 & $B A$ & $A$ & $A$ & $A$ & $B A$ & $B A$ & $B A$ \\
\hline 31 & 31-B17 & $A$ & $B A$ & $B A$ & $A$ & $B A$ & $B A$ & $B A$ \\
\hline
\end{tabular}




\begin{tabular}{|c|c|c|c|c|c|c|c|c|}
\hline \multirow[t]{2}{*}{ No } & \multirow{2}{*}{$\begin{array}{l}\text { Research Subjects } \\
\text { (with Identity Code) }\end{array}$} & \multicolumn{7}{|c|}{ Resiliency elements } \\
\hline & & RE & $\mathrm{IC}$ & $\mathrm{O}$ & $\mathrm{CA}$ & $\mathrm{E}$ & SE & $\mathrm{RO}$ \\
\hline 32 & $1-\mathrm{A} 18$ & $B A$ & $A A$ & $B A$ & $B A$ & $A$ & $B A$ & $B A$ \\
\hline 33 & 2-A18 & $B A$ & $A$ & $A$ & $A A$ & $A$ & $B A$ & $B A$ \\
\hline 34 & 3-A18 & $B A$ & $A$ & $B A$ & $A$ & $A$ & $B A$ & $B A$ \\
\hline 35 & 4-A18 & $B A$ & $A$ & $B A$ & $B A$ & $B A$ & $B A$ & $B A$ \\
\hline 36 & 5-A18 & $A$ & $A A$ & $A A$ & $A A$ & $A$ & $B A$ & $B A$ \\
\hline 37 & 6-A18 & $B A$ & $A$ & $B A$ & $B A$ & $B A$ & $B A$ & $B A$ \\
\hline 38 & 7-A18 & $A$ & $A$ & $A$ & $B A$ & $A$ & $B A$ & $B A$ \\
\hline 39 & 8-A18 & $B A$ & $A A$ & $B A$ & $A$ & $A$ & $B A$ & $B A$ \\
\hline 40 & 9-A18 & $B A$ & $A A$ & $B A$ & $A$ & $B A$ & $B A$ & $B A$ \\
\hline 41 & 10-A18 & $A$ & $A A$ & $A$ & $A$ & $A$ & $B A$ & $B A$ \\
\hline 42 & $11-\mathrm{A} 18$ & $B A$ & $A A$ & $B A$ & $B A$ & $B A$ & $B A$ & $B A$ \\
\hline 43 & $12-\mathrm{A} 18$ & $B A$ & $A A$ & $A A$ & $B A$ & $A A$ & $B A$ & $B A$ \\
\hline 44 & $13-\mathrm{A} 18$ & $B A$ & $A A$ & $A$ & $B A$ & $A$ & $B A$ & $B A$ \\
\hline 45 & $14-\mathrm{A} 18$ & $B A$ & $A$ & $A$ & $A$ & $A$ & $B A$ & $B A$ \\
\hline 46 & $15-\mathrm{A} 18$ & $B A$ & $A A$ & $B A$ & $B A$ & $B A$ & $B A$ & $B A$ \\
\hline 47 & 16-A18 & $A$ & $A A$ & $A$ & $A$ & $A$ & $B A$ & $B A$ \\
\hline 48 & 17-A18 & $A$ & $A A$ & $A$ & $A$ & $A$ & $B A$ & $B A$ \\
\hline 49 & 18-A18 & $B A$ & $A$ & $A$ & $A$ & $A$ & $B A$ & $B A$ \\
\hline 50 & 19-A18 & $B A$ & $A A$ & $B A$ & $A$ & $A$ & $B A$ & $B A$ \\
\hline 51 & 20-A18 & $B A$ & $A$ & $B A$ & $B A$ & $A$ & $B A$ & $B A$ \\
\hline 52 & 21-A18 & $B A$ & $A A$ & $A$ & $B A$ & $B A$ & $B A$ & $B A$ \\
\hline 53 & 22-A18 & $B A$ & $A$ & $B A$ & $A$ & $B A$ & $B A$ & $B A$ \\
\hline 54 & 23-A18 & $B A$ & $A A$ & $B A$ & $A$ & $A$ & $B A$ & $B A$ \\
\hline 55 & 24-A18 & $B A$ & $A A$ & $A$ & $A$ & $A$ & $B A$ & $B A$ \\
\hline 56 & 25-A18 & $B A$ & $A$ & $A$ & $B A$ & $A$ & $B A$ & $B A$ \\
\hline 57 & 26-A18 & $A$ & $A$ & $B A$ & $B A$ & $B A$ & $B A$ & $B A$ \\
\hline 58 & 27-A18 & $B A$ & $A$ & $A$ & $B A$ & $B A$ & $B A$ & $B A$ \\
\hline 59 & $28-\mathrm{A} 18$ & $B A$ & $A$ & $A$ & $A$ & $B A$ & $B A$ & $B A$ \\
\hline 60 & 29-A18 & $B A$ & $A A$ & $A$ & $A$ & $A$ & $B A$ & $B A$ \\
\hline 61 & $30-\mathrm{A} 18$ & $B A$ & $A A$ & $B A$ & $B A$ & $B A$ & $B A$ & $B A$ \\
\hline 62 & 31-A18- & $B A$ & $A A$ & $A$ & $B A$ & $A$ & $B A$ & $B A$ \\
\hline 63 & 1-B18 & $B A$ & $A A$ & $A$ & $A$ & $A$ & $B A$ & $B A$ \\
\hline 64 & 2-B18 & $B A$ & $A A$ & $B A$ & $A$ & $A$ & $B A$ & $B A$ \\
\hline 65 & 3-B18 & $B A$ & $B A$ & $A$ & $B A$ & $B A$ & $B A$ & $B A$ \\
\hline 66 & 4-B18 & $B A$ & $A A$ & $B A$ & $A$ & $A$ & $B A$ & $B A$ \\
\hline 67 & $5-B 18$ & $B A$ & $A A$ & $A$ & $B A$ & $A$ & $B A$ & $B A$ \\
\hline 68 & 6-B18 & $B A$ & $A A$ & $A$ & $A$ & $B A$ & $B A$ & $B A$ \\
\hline 69 & 7-B18 & $B A$ & $A A$ & $A$ & $B A$ & $A$ & $B A$ & $B A$ \\
\hline 70 & 8-B18 & $B A$ & $A A$ & $B A$ & $A$ & $A$ & $B A$ & $B A$ \\
\hline 71 & 9-B18 & $B A$ & $A A$ & $A$ & $A$ & $A$ & $A$ & $A$ \\
\hline 72 & 10-B18 & $B A$ & $A$ & $B A$ & $A$ & $B A$ & $B A$ & $B A$ \\
\hline 73 & 11-B18 & $B A$ & $A A$ & $A$ & $A$ & $A$ & $B A$ & $B A$ \\
\hline 74 & 12-B18 & $B A$ & $A A$ & $B A$ & $B A$ & $A$ & $B A$ & $B A$ \\
\hline 75 & 13-B18 & $B A$ & $A A$ & $A$ & $A$ & $B A$ & $B A$ & $B A$ \\
\hline 76 & 14-B18 & $B A$ & $A A$ & $B A$ & $B A$ & $B A$ & $B A$ & $B A$ \\
\hline 77 & $15-\mathrm{B} 18$ & $B A$ & $A A$ & $A$ & $A$ & $A$ & $B A$ & $B A$ \\
\hline
\end{tabular}




\begin{tabular}{ccccccccc}
\hline No & Research Subjects & \multicolumn{7}{c}{ Resiliency elements } \\
\cline { 3 - 9 } & (with Identity Code) & RE & IC & O & CA & E & SE & RO \\
\hline 78 & $16-B 18$ & $B A$ & $A A$ & $A$ & $A$ & $A$ & $B A$ & $B A$ \\
79 & $17-B 18$ & $A$ & $A A$ & $A$ & $A$ & $A$ & $B A$ & $B A$ \\
80 & $18-B 18$ & $A$ & $A A$ & $A$ & $A$ & $A$ & $A$ & $A$ \\
81 & $19-B 18$ & $B A$ & $A A$ & $B A$ & $A$ & $B A$ & $B A$ & $B A$ \\
82 & $20-B 18$ & $B A$ & $A A$ & $B A$ & $B A$ & $B A$ & $B A$ & $B A$ \\
83 & $21-B 18$ & $A$ & $A A$ & $A$ & $A$ & $A$ & $B A$ & $B A$ \\
84 & $22-B 18$ & $B A$ & $A$ & $A$ & $A$ & $A$ & $B A$ & $B A$ \\
85 & $23-B 18$ & $B A$ & $A A$ & $B A$ & $A$ & $B A$ & $B A$ & $B A$ \\
86 & $24-B 18$ & $B A$ & $A A$ & $B A$ & $B A$ & $B A$ & $B A$ & $B A$ \\
87 & $25-B 18$ & $B A$ & $A A$ & $B A$ & $B A$ & $A$ & $B A$ & $B A$ \\
88 & $26-B 18$ & $B A$ & $A A$ & $A$ & $B A$ & $B A$ & $B A$ & $B A$ \\
89 & $27-B 18$ & $B A$ & $A$ & $B A$ & $A$ & $B A$ & $B A$ & $B A$ \\
\hline
\end{tabular}

Data on table 2 showed the dominant student resiliency aspect was on the level of below average, namely owning $\geq$ 5resiliency aspects, totaling 42 peoples $(47,19 \%)$. There are no dominant students on the level of above average. There are only four students who have 3 by 4 aspects of resiliency on this level of above average, and 52 students have oneaspect of resiliency. The dominant students $(\geq 5$ aspects) were on the average level, totaling 2 peoples, 50 people shave 1 by 2 aspects of resiliency, 24 people shave 3 by 4 aspects.

\subsection{Psychogram of Counseling Students' Resiliency Level}

Table2 showed a variety of resilience profile of each students. Based on the psychogram,counselor and student can determine the guidance of priority resilience aspect. The psychogram example is presented on the following.The psychogram for all students cannot be presented here, because writing space access is limited.

Generally, the average of counseling students' resiliency, was on average level. Therefore, the students holistically need resilience reinforcement. Based on resiliency aspects, the aspects that need intensely improvement were emotion regulation, impulse control, causal analysis, empathy, andreaching out.The aspects that needs reinforcement wereoptimismandself efficacy.

\subsection{Discussion}

The research result showing averagely students has a number of problems including inclined to be high, and a large number of students resilience $(55,57 \%)$ were on the level of below average, $24,71 \%$ on average level, and $9,79 \%$ on the level of above average, soit seems there is negative impact from problems faced by students toward their resilience achievement. It means, the higher the student problems, the lower their resiliency. In other word, the problems faced by students do not impact on the resilience characteristic such as the existing of austres, bouncing, able to arise soon. Overcoming such student condition, so campus environment systemically facilitates them reducing their problems, in accordance with resilience development.

\section{Conclusion}

The problems faced by counseling students in Medan State University do not build the resilience character, on the contrary impact on decreasing the character of resilience, like the appearance of distress and undergo lectures in a monotonous manner without achievement 
orientation. This condition confirms that students need intensely resiliency improvement by employing classically and collectively guidance counseling. At the needing individual, going on next to individual assistance. Those coaching programs based on the student resilience psychogram, and paid attention to priority scale of resilience aspects were on the level of below average.It recommended for future researchers to explore the students learning motivation concerning to its impact on resilience in accomplishing the faced problems. It is important to explore whether college motivation is dominant for easy employment, so it tends to ignore the search for knowledge with great effort.

\section{References}

[1] Henderson, N. \& Milstein, M. M. (2003), Resiliency in Schools: Making It Happen for Students and Educators. California: Corwin Press, Inc.

[2] Kamus Bahasa Inggeris Indonesia. (2017), Retrieved on http://www.kamuskbbi.id/ inggris/indonesia.php?mod=view\&resilient\&id=27433-kamus-inggris-indonesia.html.

[3] Reivich, K \& Shatté, (2002), A. The Resilience Factor: 7 Essential Skills for Overcoming Life's Inevitable Obstacles. New York: Random House, Inc.

[4] Menanti, A. (2019). Analisis Peran Konselor Sebaya dalam Peningkatan Resiliensi Mahasiswa Bermasalah pada Prodi BK FIP UNIMED. Medan: Universitas Negeri Medan.

[5] Buku Pedoman Universitas Negeri Medan Tahun 2018. Medan: Universitas Negeri Medan

[6] Menanti, A. (2007), Analisis Resiliensi Ditinjau dari Tugas Perkuliahan dan Lokus Kontrol Mahasiswa Program Studi BK FIP UNIMED. Medan: Universitas Negeri Medan.

[7] Hurlock E. B.(1980), Psikologi Perkembangan: Suatu Pendekatan Sepanjang Rentang Kehidupan. (5 $5^{\text {th }}-$ Ed) Kelima. Jakarta: Erlangga.

[8] Pidgeon, Aileen M., et all. (2017), Examining Characteristics of Resilience Among University Students: An International Study. Open Journal of Social Sciences, 2, pp. 1422.

[9] Grotberg, H. (1995), A Guide to Promoting Resilience an Children: Strenghthening The Human Spirit. The Netherlands: The Bernard Van Leer Foundation.

[10] Mataro, G. (2018), Pengaruh Gaya Kepemimpinan Transformasional Kepala Sekolah terhadap Resiliensi Guru di SMA Negeri 2 Medan: Universitas Medan Area.

[11] Psychogram. Accessed: 9/12/2019 on http://en.m.wikipedia.org/wiki/Psychogram 